\title{
QUANTITATIVE RESEARCH ON THE CONCEPT OF MARKETING ASSIMILATION AND OPERATIONALIZATION BY LOCAL ORGANIZATIONS IN PRACTICE
}

\author{
Luminiţa Zaiț \\ Universitatea Vasile Alecsandri din Bacău \\ zait.luminita@yahoo.com
}

\begin{abstract}
In the last 10 years the Romanian society was in a long process of change, all the economic, social, political factors knowing a new dynamic in trying to adapt to conditions specific to new marketing environment. An important feature of Romanian society, which is relevant in the context of the proposed article, is that the economy encourages and facilitates the penetration of transnational organizations in the domestic markets with involved advantages and disadvantages. This article is part of a larger study that targeted the issue of assimilation and operationalization of the marketing concept and market orientation vision of the local organizations in the context of market globalization, to identify, on the one hand, the influence of transnational organizations on the local organizations practices, through the incorporation of marketing vision and culture, and, on the other hand, the extent to which local organizations have specific practices aligned to transnational organizations practices acting on the market in Romania.
\end{abstract}

\section{Keywords}

organizational structure; marketing department; traditional department; marketing job; overlapping competences; job description; market orientation

\section{JEL Classification}

M31

\section{Introduction}

The approach to present research started on the premise of a particular action context in which Romania, imposed by globalization of markets, requiring capacity of prospecting, synthesis, adaptation and forecast from local organizations point of view. In this context, the concept of marketing must be understood and applied depending on the particular details of this action environment.

Often, discussions about management of marketing activities and market orientation generates confusion in the local organizations. Specifically, management of marketing activity seems to get a tactic prominence by small local organizations, activities meant to facilitate the access of the products to the market. On the other hand, market orientation is wrongly understood, and it is reduced to the identification of the ways in which the business could extensively grow - expressed in terms of generating sales volume, disregarding the influence of a wide range of stakeholders on the activity of the organizations.

Through the research approach we achieved both organizational behavior description on the issue of marketing and the integration of market orientation, and we identified the transnational companies' influence on local organization regarding the integration of marketing vision and culture (Zait, 2013). This article captures a certain section of the above mentioned research, namely the degree of assimilation and 
operationalization of the marketing concept in practices of the local organizations, focusing on identifying the existence of specific organizational structure.

\section{Research methodology}

The decision issue that led to research consisted of specific knowledge of the basic elements of marketing activity and the degree of market orientation of the local organizations from different sectors, in the context of market globalization.

Defined according to the decision problem specified above, the purpose of research was to study the peculiarities of marketing and degree of market orientation, specific to local organizations in the categories of large and medium-size enterprises in several sectors.

Starting from the defined scope, objectives were developed through which has been identified concrete information for the proposed analysis (Ţimiraş, 2007). There were defined both core objectives and a number of secondary objectives, the latter being of lesser importance.

Some of the most important objectives of the research were:

- providing information on the extent to which local indigenous organizations have assimilated and implemented marketing concept (to what extent the investigated organizations: have operationalized, in the structure of the organization, a marketing department; practice marketing activities as supplementary placed in various traditional departments; coordinate their marketing activities under the principles conferred by the new concept of "marketing organization", by sectors and categories of enterprises;

- identifying the number of marketing positions within each organization;

- identify areas of marketing related in the job descriptions found for specialized staff;

- identify any overlapping of functions and tasks in job descriptions between marketing staff and the related traditional departments (research and development, trade and sales, etc.);

In our research, the research unit was the organization itself, all stated objectives, which aimed to identify the main features of the marketing activity and the integration of market orientation, being achieved after analyzing local organizations, large and medium-size, in the following sector, according to CAEN classification: mining and quarrying, manufacturing, electricity, gas and water, construction, wholesale and retail trade, hotels and restaurants, transport, storage, and communications and financial intermediation (Cătoiu et all., 2002). In the selection of investigated units was taken into account their size in terms of turnover and number of staff. There were considered in the analysis those organizations classified as medium and large-size enterprises, as defined under Law 133/1999.

Because it was intended to obtain a representative sample of the studied community, in determining its size it has required the use of statistical methods. Statistical data for determining the sample size were: community - 269 organizations; standard deviation - 33.9 (in determining this value it was considered the number of organizations by sector); probability coefficient corresponding to guarantated results for 269-1 = 268 degrees of freedom and a significance level $\alpha=0.05$ from Student distribution table 1.96; the maximum admited error of 5\%. It was obtained a sample size of 230 organizations.

Although when developing the research methodology, it was meant to provide a representative sample, in the process of information gathering it has emerged a major drawback - a low response rate of $40.43 \%$, due to the refusal of the registered organizations to participate in this research. 
As the selection process of units in the sample it was chosen proportional stratified sampling (Țimiraş and Boier, 2006). This process involved, in a first step, establishing the structure of the researched collectivity by sector and by businesses, in order to identify the weights to be applied to the statistic calculated sample. The number of units placed in the sample, which were extracted from each sector and by organizations category, has been determined so that the extracted sample to be a copy of the general community. Subsequently, in order to provide all units of the community the same chance of being selected and included in the sample research, we used random number tables.

\section{Research results}

As regards the first objective of the research - the extent to which local indigenous organizations have assimilated and implemented marketing concept, it was observed that of total organizations surveyed, $47.13 \%$ have a marketing department, while $52.87 \%$ do not have that entity in the organizational structure.

Table 1. Distribution of organizations in considered sectors in the survey and the response options on implementing the concept of marketing (whether or not have a marketing department)

\begin{tabular}{|c|c|c|c|}
\hline \multirow{2}{*}{ Sector of activity } & \multirow{2}{*}{$\begin{array}{c}\text { Total } \\
\text { organizations } \\
\text { \% }\end{array}$} & $\begin{array}{c}|c| \\
\text { Of which \% } \\
\text { have a } \\
\text { mapkartment }\end{array}$ & $\begin{array}{c}\text { do not hold a } \\
\text { marketing } \\
\text { department }\end{array}$ \\
\cline { 3 - 4 } & & 4.88 & 0.00 \\
\hline Mining and quarrying & 2.30 & 36.59 & 41.30 \\
\hline Manufacturing & 39.08 & 9.76 & 2.17 \\
\hline Electricity, gas and water & 5.75 & 17.07 & 28.26 \\
\hline Construction & 22.99 & 17.07 & 17.39 \\
\hline Wholesale and retail trade & 17.24 & 0.00 & 4.35 \\
\hline Hotels and restaurants & 2.30 & 9.76 & 6.52 \\
\hline Transport, storage, and & 8.05 & 4.88 & 0.00 \\
\hline communications & 2.30 & 100.00 & 100.00 \\
\hline Financial intermediation & 100.00 & 47.13 & 52.87 \\
\hline Total & 100.00 & & \\
\hline Of total organization & & & \\
\hline
\end{tabular}

Of all organizations which have a marketing department, most are located in the manufacturing sector $-36.59 \%$, followed by construction and trade with a share of $17.07 \%$, according to Table 1 .

Analyzing all organizations that do not have a marketing department in the organizational structure, we can see that the same hierarchy has been preserved: most organizations do not have a marketing department are located in the manufacturing sector (41.30\%), followed by construction (28.26 \%) and trade (17.39\%).

By sectors of activity, it has been observed that most marketing departments are found in organizations within extractive industry (100\%) and financial intermediation (100\%), followed by electricity, gas and water (80\%), according to the table 2 . 
Table 2. Distribution of answer options on implementing the concept of marketing (whether or not have a marketing department) in organizations within the researched sectors

\begin{tabular}{|c|c|c|}
\hline \multirow{2}{*}{ Sector of activity } & \multicolumn{2}{|c|}{ Of which \% } \\
\cline { 2 - 3 } & $\begin{array}{c}\text { have a } \\
\text { marketing } \\
\text { department }\end{array}$ & $\begin{array}{c}\text { do not hold a } \\
\text { marketing } \\
\text { department }\end{array}$ \\
\hline Mining and quarrying & 100.00 & 0.00 \\
\hline Manufacturing & 44.12 & 55.88 \\
\hline Electricity, gas and water & 80.00 & 20.00 \\
\hline Construction & 35.00 & 65.00 \\
\hline Wholesale and retail trade & 46.67 & 53.33 \\
\hline Hotels and restaurants & 0.00 & 100.00 \\
\hline Transport, storage, and communications & 57.14 & 42.86 \\
\hline Financial intermediation & 100.00 & 0.00 \\
\hline
\end{tabular}

In terms of weight, by sector, of the organizations that do not have a independent marketing department, it has been found that hotels and restaurants hold first place (100\%), followed by construction (65\%) and manufacturing (55.88 \%).

Of all the organizations surveyed, $79.31 \%$ are medium-sized organizations and $20.69 \%$ are large organizations. In the category of medium-size, it has been found that $33.33 \%$ have a marketing department, while $66.67 \%$ do not have this entity in the organizational structure.

In the large organizations category, which was the subject of the investigation, $100 \%$ of organizations have a marketing department.

Of all organizations which have a marketing department, $56.1 \%$ are medium-sized organizations and $43.9 \%$ are large organizations. Organizations that do not have a marketing department are just the medium-size organizations category.

A structure for organizations in considered sectors, the response options - have / do not have a marketing department, is presented in Table 3.

According to Table 3, most midsize organizations which have a marketing department are located in sectors like manufacturing (34.78\%) and wholesale and retail trade (21.74\%). Of all large organizations which have a marketing department, it was found that most are located in manufacturing (38.89\%), followed by construction with $22.22 \%$.

Table 3. Distribution of organizations in the considered sectors by the response options on implementing the concept of marketing (whether or not a marketing department) and by businesses

\begin{tabular}{|c|c|c|c|c|}
\hline \multirow{4}{*}{ Sector of activity } & \multicolumn{4}{|c|}{ Of which \% } \\
\hline & \multicolumn{2}{|c|}{ have a marketing department } & \multicolumn{2}{|c|}{$\begin{array}{c}\text { do not hold a marketing } \\
\text { department }\end{array}$} \\
\hline & \multicolumn{4}{|c|}{ Organization category \% } \\
\hline & Medium-size & Large & Medium-size & Large \\
\hline Mining and quarrying & 4.35 & 5.56 & 0.00 & 0.00 \\
\hline Manufacturing & 34.78 & 38.89 & 41.30 & 0.00 \\
\hline Electricity, gas and water & 8.70 & 11.11 & 2.17 & 0.00 \\
\hline Construction & 13.04 & 22.22 & 28.26 & 0.00 \\
\hline
\end{tabular}



BY LOCAL ORGANIZATIONS IN PRACTICE

\begin{tabular}{|c|c|c|c|c|}
\hline Wholesale and retail trade & 21.74 & 11.11 & 17.39 & 0.00 \\
\hline Hotels and restaurants & 0.00 & 0.00 & 4.35 & 0.00 \\
\hline $\begin{array}{c}\text { Transport, storage, and } \\
\text { communications }\end{array}$ & 8.70 & 11.11 & 6.52 & 0.00 \\
\hline Financial intermediation & 8.70 & 0.00 & 0.00 & 0.00 \\
\hline
\end{tabular}

Out of all medium-sized organizations that do not have a marketing department, it was observed that most are found in manufacturing (41.3\%), followed by construction (28.26\%) and wholesale trade (17.39\%). A low presence of marketing departments was found both in the category of medium-sized organizations and in the category of large organizations, in extractive industry sector $-4.35 \%$ and $5.56 \%$.

Because the present study aims to identify the existence of marketing activities, including the organizations that do not have marketing department, we wanted to know where are placed such activities in the traditional departments. Thus, of all the organizations that do not have a marketing department, $95.65 \%$ indicated that marketing activities are located in various traditional departments, and only $4.35 \%$ have checked the option that they have no marketing activities.

Of all organizations that do not have a marketing department, it was found that the largest share regarding traditional structures where marketing activities are located is owned by sales or trading department (53.25\%), followed by R \& D (18.18\%) , manufacturing (10.39\%) and public relations (9.09\%).

As can be seen from Table 4, the R \& D department was noted in $57.14 \%$ of cases (total responses) of respondents from the manufacturing sector, followed by construction (35.71\%). Production department as an entity that holds marketing activities, was mentioned only in the manufacturing sector, while sales and trading department was mentioned in $43.9 \%$ of cases by manufacturing, followed by construction (26.83\%) and wholesale and retail trade (17.07\%).

Table 4. Distribution of organizations in considered sectors by response options on traditional deparments where are located the marketing activities

\begin{tabular}{|c|c|c|c|c|c|c|}
\hline \multirow{2}{*}{ Sector of activity } & \multicolumn{6}{|c|}{ The frequency regarding departments where are localized marketing } \\
& \multicolumn{1}{|c|}{$\boldsymbol{A}$} & $\boldsymbol{B}$ & $\boldsymbol{C}$ & $\boldsymbol{D}$ & $\boldsymbol{E}$ & $\boldsymbol{F}$ \\
\hline & 0.00 & 0.00 & 0.00 & 0.00 & 0.00 & 0.00 \\
\hline $\begin{array}{c}\text { Mining and } \\
\text { quarrying }\end{array}$ & 57.14 & 100.00 & 43.90 & 42.86 & 0.00 & 50.00 \\
\hline Manufacturing & 7.14 & 0.00 & 2.44 & 0.00 & 0.00 & 0.00 \\
\hline $\begin{array}{c}\text { Electricity, gas } \\
\text { and water }\end{array}$ & 35.71 & 0.00 & 26.83 & 0.00 & 60.00 & 0.00 \\
\hline Construction & 0.00 & 0.00 & 17.07 & 14.29 & 20.00 & 50.00 \\
\hline $\begin{array}{c}\text { Wholesale and } \\
\text { retail trade }\end{array}$ & 0.00 & 0.00 & 2.44 & 28.57 & 0.00 & 0.00 \\
\hline $\begin{array}{c}\text { Hotels and } \\
\text { restaurants }\end{array}$ & 0.00 & 0.00 & 7.32 & 14.29 & 20.00 & 0.00 \\
\hline $\begin{array}{c}\text { Transport, } \\
\text { storage, and } \\
\text { communications }\end{array}$ & 0.00 & 0.00 & 0.00 & 0.00 & 0.00 & 0.00 \\
\hline $\begin{array}{c}\text { Financial } \\
\text { intermediation }\end{array}$ & 0.00 \\
\hline
\end{tabular}

Legend: A - Research and Development; B - Production; C - Commercial / Sales; D - Public Relations; E Other departments: Financial \& Accounting; F - Within our organization we do not conduct marketing activities 
Distribution of answer regarding the traditional departments where are located the marketing activities by organizations in considered sectors is shown in Table 5 .

Sectors of activity at which marketing activities are developed within traditional departments are:

- manufacturing sector - $21.05 \%$ in production, $21.05 \%$ in $\mathrm{R} \& \mathrm{D}, 47.37 \%$ in commercial or sales, $7.89 \%$ in public relations, $2.63 \%$ of the organizations indicated that they have no marketing activities.

- wholesale and retail trade - 70\% in sales and trading, $10 \%$ in PR and $10 \%$ in finance and accounting; $10 \%$ of organizations indicated that they are not performing marketing activities.

- Construction - 26.32\% in R \& D, 57.89\% in sales and trading, $15.79 \%$ in financial \& accounting.

As regards the existence of marketing positions within local organizations, we obtained the following structure: $63.22 \%$ holding marketing positions allocated to specialists, located in marketing or traditional compartments, $34.48 \%$ do not hold marketing positions, but tasks related to this field are found in other jobs with economic studies, while $2.3 \%$ indicated that they have no marketing activities.

Table 5. Distribution, within organizations from the considered sectors in the analysis, of the answer options regarding traditional departments where are located the marketing activities

\begin{tabular}{|c|c|c|c|c|c|c|c|}
\hline \multirow{2}{*}{ Sector of activity } & \multirow{2}{*}{$\begin{array}{c}\text { Total } \\
\text { answers } \\
\text { \% }\end{array}$} & \multicolumn{6}{|c|}{ The frequency regarding departments where are localized } \\
\cline { 3 - 8 } & & $\boldsymbol{A}$ & $\boldsymbol{B}$ & $\boldsymbol{C}$ & $\boldsymbol{D}$ & $\boldsymbol{E}$ & $\boldsymbol{F}$ \\
\hline $\begin{array}{c}\text { Mining and } \\
\text { quarrying }\end{array}$ & 0.00 & 0.00 & 0.00 & 0.00 & 0.00 & 0.00 & 0.00 \\
\hline Manufacturing & 49.35 & 21.05 & 21.05 & 47.37 & 7.89 & 0.00 & 2.63 \\
\hline $\begin{array}{c}\text { Electricity, gas } \\
\text { and water }\end{array}$ & 2.60 & 50.00 & 0.00 & 50.00 & 0.00 & 0.00 & 0.00 \\
\hline Construction & 24.68 & 26.32 & 0.00 & 57.89 & 0.00 & 15.79 & 0.00 \\
\hline $\begin{array}{c}\text { Wholesale and } \\
\text { retail trade }\end{array}$ & 12.99 & 0.00 & 0.00 & 70.00 & 10.00 & 10.00 & 10.00 \\
\hline $\begin{array}{c}\text { Hotels and } \\
\text { restaurants }\end{array}$ & 3.90 & 0.00 & 0.00 & 33.33 & 66.67 & 0.00 & 0.00 \\
\hline $\begin{array}{c}\text { Transport, } \\
\text { storage, and } \\
\text { communications }\end{array}$ & 6.49 & 0.00 & 0.00 & 60.00 & 20.00 & 20.00 & 0.00 \\
\hline $\begin{array}{c}\text { Financial } \\
\text { intermediation }\end{array}$ & 0.00 & 0.00 & 0.00 & 0.00 & 0.00 & 0.00 & 0.00 \\
\hline
\end{tabular}

Legend: A - Research and Development; B - Production; C - Commercial / Sales; D - Public Relations; E Other departments: Financial \& Accounting; F - Within our organization we do not conduct marketing activities

Of all organizations which have a marketing department, 97.5\% have marketing positions allocated to specialists, while $2.5 \%$ do not possess marketing positions, but develop such activities (within the marketing department) by profesionists in economics.

Of all the organizations that do not have a marketing department, 32.61\% hold marketing positions allocated to marketers, $63.04 \%$ have no marketing positions, but the tasks are assigned to other posts with or without economic studies, while $4.35 \%$ have no marketing activities.

Distribution of organizations in the considered sectors in the analysis on category units, by the response options on marketing positions is presented in Table 6 . 


\section{QUANTITATIVE RESEARCH ON THE CONCEPT OF MARKETING ASSIMILATION AND OPERATIONALIZATION BY LOCAL ORGANIZATIONS IN PRACTICE}

It can thus be seen that most midsize organizations that have between 1 and 5 marketing positions allocated to specialists, are found in sectors such as wholesale and retail trade (36\%), construction (24\%) and transport, storage and communications (12\%).

Among midsize organizations that have between 6 and 10 marketing positions allocated to specialists, most are found in sectors such as manufacturing (72.73\%), followed by construction (18.18\%).

Between 11 and 15 marketing specialists are found in medium-size organizations, only in the manufacturing sector.

Table 6. Distribution of organizations in the considered sectors by response options on marketing positions

\begin{tabular}{|c|c|c|c|c|c|c|}
\hline \multirow{4}{*}{ Sector of activity } & \multicolumn{6}{|c|}{ Category of organization \% } \\
\hline & \multicolumn{6}{|c|}{ Medium-size } \\
\hline & \multicolumn{6}{|c|}{ Marketing positions \% } \\
\hline & $A$ & B & $C$ & $\boldsymbol{D}$ & $\boldsymbol{E}$ & $\boldsymbol{F}$ \\
\hline Mining and quarrying & 4.00 & 0.00 & 0.00 & 0.00 & 0.00 & 0.00 \\
\hline Manufacturing & 8.00 & 72.73 & 100.0 & 51.72 & 0.00 & 50.00 \\
\hline $\begin{array}{l}\text { Electricity, gas and } \\
\text { water }\end{array}$ & 4.00 & 9.09 & 0.00 & 3.45 & 0.00 & 0.00 \\
\hline Construction & 24.00 & 18.18 & 0.00 & 27.59 & 0.00 & 0.00 \\
\hline $\begin{array}{l}\text { Wholesale and retail } \\
\text { trade }\end{array}$ & 36.00 & 0.00 & 0.00 & 10.34 & 0.00 & 50.00 \\
\hline Hotels and restaurants & 4.00 & 0.00 & 0.00 & 0.00 & 100.0 & 0.00 \\
\hline $\begin{array}{c}\text { Transport, storage, and } \\
\text { communications }\end{array}$ & 12.00 & 0.00 & 0.00 & 6.90 & 0.00 & 0.00 \\
\hline Financial intermediation & 8.00 & 0.00 & 0.00 & 0.00 & 0.00 & 0.00 \\
\hline \multirow{4}{*}{ Sector of activity } & \multicolumn{6}{|c|}{ Category of organization \% } \\
\hline & \multicolumn{6}{|c|}{ Large-size } \\
\hline & \multicolumn{6}{|c|}{ Marketing positions \% } \\
\hline & $A$ & $\boldsymbol{B}$ & $C$ & $\boldsymbol{D}$ & $\boldsymbol{E}$ & $\boldsymbol{F}$ \\
\hline Mining and quarrying & 0.00 & 11.11 & 0.00 & 0.00 & 0.00 & 0.00 \\
\hline Manufacturing & 60.00 & 22.22 & 50.00 & 0.00 & 0.00 & 0.00 \\
\hline $\begin{array}{c}\text { Electricity, gas and } \\
\text { water }\end{array}$ & 0.00 & 11.11 & 25.00 & 0.00 & 0.00 & 0.00 \\
\hline Construction & 0.00 & 33.33 & 25.00 & 0.00 & 0.00 & 0.00 \\
\hline $\begin{array}{l}\text { Wholesale and retail } \\
\text { trade }\end{array}$ & 0.00 & 22.22 & 0.00 & 0.00 & 0.00 & 0.00 \\
\hline Hotels and restaurants & 0.00 & 0.00 & 0.00 & 0.00 & 0.00 & 0.00 \\
\hline $\begin{array}{c}\text { Transport, storage, and } \\
\text { communications }\end{array}$ & 40.00 & 0.00 & 0.00 & 0.00 & 0.00 & 0.00 \\
\hline Financial intermediation & 0.00 & 0.00 & 0.00 & 0.00 & 0.00 & 0.00 \\
\hline
\end{tabular}

A - 1-5 marketing specialists; B - 6 to 10 marketing specialists; C - 11 to 15 marketing specialists; D Marketing tasks are included in the job descriptions of staff with economic studies, but they do not have marketing diploma and are not employed on marketing positions; E - marketing tasks are included in the job descriptions of specialists from many professions (from different departments): programmers, engineers, sociologists, etc.; F - don`t have staff employed in marketing activities 
In the medium-sized organizations, marketing tasks localized in the job related to economics, but without marketing specialization can be found in the highest proportion in sectors such as manufacturing (51.72\%) and construction (27.59\%).

Only in hotels and restaurants, from medium-sized organizations were identified marketing tasks in the job description of personnel outside the economic domain.

In the case of large organizations were mentioned: between 1 and 5 marketing positions in the largest share, in the manufacturing sector (60\%); between 6 and 10 marketing specialists in construction (33.33\%); from 11 to 15 specialists in marketing for manufacturing (50\%). Marketing tasks are not assigned to the staff from other fields.

The largest number of marketing positions (11 to 15) is found at the level of mediumsize organizations, in sectors such as manufacturing and at large organizations in sectors such as: manufacturing (50\%); electricity, gas and water (25\%) and construction (25\%).

As regards the areas of marketing found in the job descriptions of specialist staff, in the sample we found the following frequencies: in $10.84 \%$ of cases (total responses) were mentioned activities such as: marketing planning, implementation of plans and marketing programs, control of marketing plans and programs; in $8.74 \%$ of cases were specified analysis and marketing research activities; in $7.69 \%$ of cases were mentioned forecasting and modeling activities on product and price; in $29.72 \%$ of cases were specified activities related to forecasting and modeling the market; in $25.17 \%$ of cases were mentioned activities related to the sales force and distribution; in $17.83 \%$ of cases were mentioned activities related to communication.

Information, centralized by answer choice, as in Table 7 , shows the following structure on areas of interest:

- highest frequency of occurrence of marketing planning activities, implementation and control was recorded in the manufacturing industry (45.16\%), followed by electricity and energy sectors, construction and transport by the same percentage, $12.9 \%$;

- marketing research and analysis activities were mentioned in 52\% of cases by organizations in the manufacturing sector, followed by organizations in wholesale and retail trade (28\%);

- forecasting and modeling activities on product and price were mentioned in $27.27 \%$ of cases by organizations in sectors such as manufacturing or transport, storage and trade, followed by electricity, gas and water (18.18\%);

- forecasting and market modeling related activities were mentioned with the highest frequency in sectors such as manufacturing (38.82\%), construction (23.53\%) and trade (16.47\%);

- highest frequency of occurrence of the activities related to the sales force and distribution were recorded in the manufacturing sector $(40.28 \%)$, followed by construction (23.61\%) and trade (19.44\%);

- promotional activities were mentioned with the highest frequency in the manufacturing industry (41.18\%) and trade (27.45\%).

By categories of enterprises, according to Table 8, were found the following:

- at medium-sized companies were mentioned, with the highest frequency, forecasting and market modeling related activities (34.54\%), followed by sales force and distribution (27.84\%) and promotional activities (17.53\%); in this category the lowest frequencies were recorded for forecasting and modeling activities on product and price (3.61\%);

- among larger firms, the higher frequencies were registered for activities related to forecasting and market modeling, sales force and distribution respectively $(19.57 \%)$, followed by promotional activities $(18.48 \%)$; the 


\section{QUANTITATIVE RESEARCH ON THE CONCEPT OF MARKETING ASSIMILATION AND OPERATIONALIZATION BY LOCAL ORGANIZATIONS IN PRACTICE}

lowest frequencies were recorded in the activities related to marketing research and analysis $(11.96 \%)$.

Table 7. Distribution of organizations in considered sectors by response options in the areas of marketing found in the job descriptions of specialists

\begin{tabular}{|c|c|c|c|c|c|c|c|}
\hline \multirow{2}{*}{ Sector of activity } & \multicolumn{7}{|c|}{ The frequency of areas of marketing found in job descriptions of } \\
\cline { 2 - 8 } & $\boldsymbol{A}$ & $\boldsymbol{B}$ & $\boldsymbol{C}$ & $\boldsymbol{D}$ & $\boldsymbol{E}$ & $\boldsymbol{F}$ & $\boldsymbol{G}$ \\
\hline $\begin{array}{c}\text { Mining and } \\
\text { quarrying }\end{array}$ & 6.45 & 0 & 9.09 & 2.35 & 1.39 & 0.00 & 0 \\
\hline Manufacturing & 45.16 & 52 & 27.27 & 38.82 & 40.28 & 41.18 & 0 \\
\hline $\begin{array}{c}\text { Electricity, gas and } \\
\text { water }\end{array}$ & 12.90 & 0 & 18.18 & 5.88 & 0.00 & 1.96 & 0 \\
\hline Construction & 12.90 & 4 & 4.55 & 23.53 & 23.61 & 11.76 & 0 \\
\hline $\begin{array}{c}\text { Wholesale and } \\
\text { retail trade }\end{array}$ & 3.23 & 28 & 4.55 & 16.47 & 19.44 & 27.45 & 0 \\
\hline $\begin{array}{c}\text { Hotels and } \\
\text { restaurants }\end{array}$ & 0.00 & 0 & 0.00 & 2.35 & 2.78 & 3.92 & 0 \\
\hline $\begin{array}{c}\text { Transport, storage, } \\
\text { and } \\
\text { communications }\end{array}$ & 12.90 & 8 & 27.27 & 8.24 & 9.72 & 9.80 & 0 \\
\hline $\begin{array}{c}\text { Financial } \\
\text { intermediation }\end{array}$ & 6.45 & 8 & 9.09 & 2.35 & 2.78 & 3.92 & 0 \\
\hline
\end{tabular}

Legend:

A - a. Marketing planning, b. Implementing marketing plans and programs c. Control of marketing plans and programs; B - d. Marketing research and analysis (market environment, competition); C - e. Forecasting and modeling (product, price); D - f. Forecasting and modeling (market); E - g. Sales force and distribution; F - h. Promotional activities (advertising, sales promotion, public relations, trade shows and exhibitions); G - i. Other marketing services

Table 8. Distribution by category of organizations of marketing domains found in the job descriptions of specialists

\begin{tabular}{|c|c|c|c|c|c|c|c|}
\hline \multirow{2}{*}{ Category of organization } & \multicolumn{7}{|c|}{ The frequency of areas of marketing found in job } \\
& \multicolumn{7}{|c|}{ descriptions of marketers \% } \\
\cline { 2 - 8 } & $\boldsymbol{A}$ & $\boldsymbol{B}$ & $\boldsymbol{C}$ & $\boldsymbol{D}$ & $\boldsymbol{E}$ & $\boldsymbol{F}$ & $\boldsymbol{G}$ \\
\hline Medium-sized organizations & 9.28 & 7.22 & 3.61 & 34.54 & 27.84 & 17.53 & 0.00 \\
\hline Large organizations & 14.13 & 11.96 & 16.30 & 19.57 & 19.57 & 18.48 & \multirow{2}{*}{0.00} \\
\hline
\end{tabular}

Legend:

A - a. Marketing planning, b. Implementing marketing plans and programs c. Control of marketing plans and programs; B - d. Marketing research and analysis (market environment, competition); C - e. Forecasting and modeling (product, price); D - f. Forecasting and modeling (market); E - g. Sales force and distribution; F - h. Promotional activities (advertising, sales promotion, public relations, trade shows and exhibitions); G - i. Other marketing services

Regarding any possible overlapping of responsibilities and tasks in job descriptions between marketing staff and the staff of traditional departments (research and development, trade and sales etc.), of all organizations that responded to this question, $74.12 \%$ said there are such overlaps in their activities, and $25.88 \%$ have specified their absence.

By categories of organizations, from those that mentioned the existence of overlapping of functions and tasks of the job descriptions between marketing staff and the staff of traditional departments, $84.13 \%$ are medium-sized companies and $15.87 \%$ are large enterprises. The structure of organizations that have specified no 
overlapping of duties between marketing staff and the staff of traditional divisions is as follows: $63.64 \%$ are medium-size organizations and $36.36 \%$ are large organizations.

Distribution of organizations in the studied sectors by the response options offered by the two categories of enterprises is presented in Table 9.

Table 9. Distribution of organizations within the researched sectors by the answer on overlapping of tasks and responsibilities between marketing staff and the staff of traditional departments

\begin{tabular}{|c|c|c|c|c|}
\hline \multirow{4}{*}{ Sector of activity } & \multicolumn{4}{|c|}{ The frequency of duplication of tasks\% } \\
\hline & \multicolumn{4}{|c|}{ Category of organization } \\
\hline & \multicolumn{2}{|c|}{ Medium-size } & \multicolumn{2}{|c|}{ Large-size } \\
\hline & $A$ & B & $A$ & B \\
\hline Mining and quarrying & 1.89 & 0.00 & 10.00 & 0.00 \\
\hline Manufacturing & 39.62 & 35.71 & 30.00 & 50.00 \\
\hline Electricity, gas and water & 3.77 & 7.14 & 10.00 & 12.50 \\
\hline Construction & 24.53 & 21.43 & 20.00 & 25.00 \\
\hline Wholesale and retail trade & 22.64 & 0.00 & 20.00 & 0.00 \\
\hline Hotels and restaurants & 1.89 & 7.14 & 0.00 & 0.00 \\
\hline $\begin{array}{c}\text { Transport, storage, and } \\
\text { communications }\end{array}$ & 5.66 & 14.29 & 10.00 & 12.50 \\
\hline Financial intermediation & 0.00 & 14.29 & 0.00 & 0.00 \\
\hline
\end{tabular}

Legend:

A - there are overlaps of responsibilities and tasks between marketing staff and the staff of traditional departments

B - there is no overlap of responsibilities and tasks between marketing staff and the staff of traditional departments

Overlapping of responsibilities between marketing staff and the staff of traditional departments was mentioned with the highest frequency by category of organizations as follows:

- In $39.62 \%$ of cases by midsize organizations in the manufacturing sector, followed by those in construction sector (24.53\%) and trade (22.64\%);

- For large organizations, the highest frequencies were recorded in the manufacturing sector (30\%), followed by construction sector (20\%) and trade (20\%).

Lack of duplication of duties between marketing staff and the staff of traditional departments was recorded with the highest frequencies in sectors such as manufacturing (35.71\% and 50\%) and construction (21.43\% and 25\% respectively), both for medium and for larger organizations.

The lowest frequencies, regarding the existence of overlapping of functions, were recorded in sectors such as the extractive industry (1.89\%) and hotels and restaurants (1.89\%) for midsize organizations, and transport, storage, communications, mining and electricity, gas and water (10\%) for large organizations.

\section{Conclusions}

The research results confirm both above average level of assimilation and operationalization of the marketing concept in the practices of indigenous organizations and partial accuracy of the hypothesis previously released, namely the importance of marketing tends to be underestimated in these organizations. 


\section{References}

Cătoiu, I., Balan, C., Popescu, I. C., Orzan, Ghe., Veghes, C., Danetiu, T., Vranceanu, D. (2002) - Cercetări de marketing, Bucureşti, Editura Uranus.

Timiras, L., Boier, R. (2006), Cercetarea de marketing, Iaşi, Editura Performantica

Timiras, L. (2007) Evoluţia marketingului agroalimentar din România în contextul extinderii Uniunii Europene, Bacău, Editura EduSoft.

Zaiţ, L. (2009), The process of marketing management - between the management marketing activities and the operational marketing, Studies and Scientific Researches, Edition Economics, issue 14, 129-136.

Zaiţ, L. (2013), Managementul marketingului în contextul globalizării pieţelor, Bacău, Editura Alma Mater. 